\title{
A Proteção dos Interêsses do Fisco nos Processos Falimentares
}

\section{ARNOLd WALD}

A lei de falência no seu artigo 174 determina que, nos processos de concordata preventiva "entregue o relatório do comissário (artigo 169, n. ${ }^{\circ} \mathrm{X}$ ) o escrivão dentro de vinte e quatro horas:

I - Se o devedor não tiver exibido، até então, prova do pagamento dos impostos relativos à profissão, federais, estaduais e municipais, e das contribuições devidas ao Instituto ou Caixa de Aposentadoria e Pensões do ramo de indústria ou comércio a que pertencer, fará os autos conclusos ao juiz para que êste, com observância do parágrafo primeiro do art. 162 decrete a falência".

O parágrafo primeiro do art. 162 se refere aos requisitos da sentença declaratória de falência.

E' evidente que pela sua própria redação o artigo 174 não admite derogação por parte dos juízes. E' uma norma de ordem pública que não deixa poder discricionário aos magistrados. Não pagos os impostos, a falência deve ser declarada imediatamente. Tal é a conclusão que emana do próprio texto da disposição legal e da lição da jurisprudência e da doutrina.

Trajano de Miranda Valverde, nos seus Comentários à lei de falências ("Revista Forense", 1948, $2 .^{\circ}$ vol., p. 340), observa que "O juiz não tem a faculdade de conceder prazo de tolerância, pois o preceito, como outros semelhantes, visa a defesa dos legítimós interêsses da fazenda pública, federal, estadual ou municipal, e dos daquelas instituições cujos créditos são equiparados aos da fazenda pública. Gozam de privilégio e não entram em concurso de credores. Mas, se o juiz não pode conceder prazo de tolerância ou de graça, é certo que não deverá decretar a falência, se até antes de proferir a sua decisão conseguir o devedor a prova do pagamento dos impostos e contribuições devidos. E a decisão do juiz terá que ser dada nas 24 horas seguintes à conclusão dos autos".

Não obstante os têrmos imperativos da lei, os juízes continuam algumas vêzes a conceder novos prazos de tolerância prejudicando não só os credores 
mas a própria fazenda pública, para não decretar a falência, olvidando que a concordata é um benefício concedido ao comerciante honesto e infeliz, cumpridơr das suas obrigações e favorecendo assim a chamada "indústria das concordatas".

Necessário se torna que o legislador estabeleça de forma mais nítida ainda a obrigação que o juiz tem, em determinados casos, de transformar a concordata em falência sob pena de responsabilidade pessoal, comơ nos casos de desrespeito aos prazos legalmente estabelecidos.

No es ha cer obra de organizador, oponer el Hombre a la Organización, como se ha intentato ha cer como consecuencia de los errores cometidos a veces por los precursores. En nuestros dias estos errores se perpetuan por la aplicación inconsiderada de ciertos procedimientos de Organización que la rebajan al nivel de "sistemas" cuyos resultados nefastos han comprometido la causa misma de la Organización frente a los obreros, a los patrones y a la opinión pública.

A este respecto, se puede decir que, por ejemplo, el cronometraje, tan útil y tan necessario, sin el cual no se puede lograr una justicia en el trabajo ni ordenar racionalmente la producción, es utilizado con demasiada frecuencia fuera de la filosofia, del espíritu y de la técnica de la verdadera Organización Cientifica.

Henri Cabanie - In "Universidad" - N. $30-1955$ - pg. 90. 